\title{
Mapping Impacts of Crude Oil theft and Illegal Refineries on Mangrove of the Niger Delta of Nigeria with Remote Sensing Technology
}

\author{
Balogun, Toju Francis \\ Department of Geography and Regional Planning, University of Benin, Benin City \\ tobalogun@yahoo.com
}

\section{Doi:10.5901/mjss.2015.v6n3p150}

\begin{abstract}
Niger Delta is the oil rich region of Nigeria where extensive mangrove form one of the most important ecosystems of coastal and marine areas. It is a fragile ecosystem rich in biodiversity. The mangrove is exposed to the activities of crude oil bunkering and illegal refinery. This study aims at mapping the impacts of the crude oil theft and illegal refineries on the creeks and mangroves of the Niger Delta.Worldview-2 2013 satellite image was processed using supervised classification methods and Normalized Difference Vegetation Index (NDVI). Oil on the waterways covering estimated area of $9.2 \mathrm{~km}^{2}$ and stressed mangrove vegetation covering estimated area of $37.6 \mathrm{~km}^{2}$ were detected. Result of NDVI shows positive correlation with photosynthetic activities as areas with stressed vegetation around the illegal refineries had low vegetation index of -0.39 while areas with healthier vegetation had higher index of 0.55 . Since illegal refineries and crude oil theft is rampant in the region, the paper recommends a regional study of the state of the mangrove in the Niger Delta.
\end{abstract}

Keywords: Bunkering, sabotage, environmental sensitivity index, remediation, mangrove recovery

\section{Introduction}

Nigeria is the largest producer of petroleum in Africa and the $5^{\text {th }}$ among the Organization of Petroleum Exporting Countries (OPEC). In the first quarter of the year in 2013 the daily crude oil production in Nigeria fluctuated between 1.86 and 2.1 million barrels per day as against the estimated $2.48 \mathrm{mbpd}$. This drop was linked to the incessant crude oil theft and vandalisation of pipelines. Though oil bunkering started as far back as 2003 when it was done as an act of vandalism to make the oil company pay compensation for oil spill it later graduated to stealing and selling/ processed and sell. Oil theft and illegal refinery became escalated and full blown in 2012 after the militants were granted amnesty. In the first half of the year 2012, the Nigerian government estimated as many as 400,000 barrels of crude oil being stolen each day, costing the nation up to $\$ 1$ billion per month in lost revenues. Baird (2010) observed that oil siphoning has become a big business, with the stolen oil quickly making its way into the black market. Some of the oil is delivered to small scale rudimentary refineries in the creeks and mangroves. Here it is boiled to produce low grade diesel fuel.

According to Anderson (2005) sabotage is performed primarily through what is known as "bunkering", whereby the saboteur attempts to tap the pipeline. Oil spills occur at every stage of the bunkering process. In the process of extraction sometimes the pipeline is damaged or destroyed. Damaged lines may go unnoticed for days, and repair of the damaged pipes takes even longer. Attah, (2012) noted that the activities of the saboteur is more than Nigeria losing money from lost production, costly repairs and clean-up and facility downtime. It is a sad story of consistent pollution of farm lands and rivers by people who are not bothered by the effects of their actions on the environment.

The Joint Task Force (the Niger Delta-focused security unit) set up by the government reported that in the first quarter of the year 2013, it destroyed 3,778 illegal refineries and seized eight vessels, 120 barges, 878 boats, 178 fuel pumps, 5238 surface tanks, 606 pumping machines and 626 outbound engines allegedly belonging to oil thieves (Africapractice, 2012). In spite of these efforts the crude theft has not abated. Crude theft is not only economic loss to the government and the people but also environmentally detrimental. This study looks at the impacts of crude oil theft on the mangrove environment.

\section{Literature Review}

Nigeria is blessed with a large expanse of mangrove forests estimated to cover approximately 5,000 to $8,580 \mathrm{~km}^{2}$ of land of the Niger Delta. The mangroves belong to a fragile ecosystem and are exposed to oil spill due to oil exploration either 
through accident or sabotage which usually results into environmental degradation. Blasco et al. (1996) observed that if oil directly affects any organism within an ecosystem, it can indirectly affect a host of other organisms. Mangrove ecosystems support aquatic food chains and form habitats for marine fauna, such as juvenile crabs, prawns, offshore fish, reef fish, and larvae (Manson, et al, 2005; Mumby, et al 2004; Nagelkerken, et al, 2008; Naylor et al, 2000). Terrestrial fauna, such as birds, insects, mammals, and reptiles, and associated flora, such as fungi, algae, and sea grass, build rich communities within mangroves (Kathiresan, et al, 2001, Mumby, et al 2004; Nagelkerken, et al, 2008, Cannicci et al, 2008). Mangroves are important for the carbon balance of the coastal zone (Boullion, et al, (2008); Kristensen, (2008). According to Kuenzer (2011) mangrove ecosystems provide various ecological and economical ecosystem services contributing to coastal erosion protection, water filtration, provision of areas for fish and shrimp breeding, provision of building material and medicinal ingredients, and the attraction of tourists, amongst many other factors. The effects of oil spills on mangroves are known to acidify the soils, halt cellular respiration, and starve roots of vital oxygen.

As important as mangroves ecosystem is, it belong to the most threatened and vulnerable ecosystems worldwide. In order of increasing vulnerability, the mangroves and intertidal shores of the Niger Delta fall under categories 8 to 10 on the environmental sensitivity index (ESI) scale, which predisposes the areas to serious long-term effects and clean-up complexity (Osuji, Erondu and Ogali, 2010). Physiographic types of mangroves, oil type and length of mangrove's exposure all combine in different permutations to determine the impacts of oil spill on the mangrove. In terms of physiographic types, of mangroves and length of mangrove's exposure to spilled oil, Lewis (1979) opines defoliation and death of small $(<1 \mathrm{~m})$ mangrove coupled with loss of aerial root community (bostrychietum) within 15 to 30 days of exposure. Chan (1977) and Lewis (1980) observed defoliation and death of medium $(<3 \mathrm{~m})$ mangrove coupled with damage of aerial roots' tissue within 30 days to 1 year of exposure. Snedaker et al (1981) suggests death of larger $(<3 \mathrm{~m})$ mangroves and loss of impacted aerial roots within 1 and 5 years of exposure to spilled oil. Mangrove mortality tends to be highest among propagules, seedlings, and juvenile trees. An area of mangroves that has been destroyed by petroleum may be susceptible to other problems. The area may not be suitable for any native plant growth until bacteria and microorganisms can remediate the conditions. Boyer (1982) observed that the impact of environmental stress on the physiological processes of a plant defines a crop's overall productivity. Unfavorable environmental conditions can reduce yields by more than $70 \%$. Basso (2004) also observed that the consequence of stressful growing conditions is a decline in leaf chlorophyll concentrations, a decrease in incident light absorbance, and a reduction in overall plant productivity (Carter et al., 2001; Zhao et al., 2003).

The destruction of mangrove ecosystems can reduce production of coastal fisheries, because mangrove forests serve as breeding and nursery grounds for many commercial species of fish, crustaceans and mollusks (Boyd and Tucker, 1998; Ramachandran et.al, 1998). In the Delta Mangrove wood is a source of fuel, either as charcoal or firewood, and is a primary material for the construction of boats, houses, furniture, etc. Timber resources and particularly nontimber forest product (NTFRs) are critical sources of income for many rural household. In River State alone, the estimated value of NTFRs may exceed USD 100 million annually (Ruitenbeck, 1990).

According to Lewis (1983) mangrove forest complete recovery period from oil spill impacts takes 10 to 50 years. As he noted, the pattern of damage and recovery of mangrove vegetation from oil spill impact is a function of a number of factors in time. He identified four determinants: type of spilled oil, the amount of spilled oil reaching the mangroves, the amount remaining after any cleanup effort and the various physiographic types of mangroves affected. Other factors identified by other authors are length of mangrove's exposure to spilled oil (Shigenaka, 2002), site conditions (Jacobi and Schaeffer-Novelli, 1990) and the type of remediation technique employed (Proffitt et al., 1996).

Since the mangrove is important to the indigenous people of Nigeria as well as to the various organisms that inhabit these ecosystems thus up-to-date information with regard to the extent and condition of mangrove ecosystems is an essential aid to management and policy- and decision-making processes. Hence Kuenzer, (2011) noted that the goal of all remote-sensing-based mangrove mapping and monitoring activities should be the protection of these unique ecosystems, whose value cannot be overestimated.

\section{Research Methodology}

Awoba and Krakrama are major settlements in Degema Local Government Area in Rivers State of Nigeria. The Local government is located within the mangrove forest. Traditional field survey are not effective to acquire vegetation condition over a large, impenetrable and unsecured area because it is unsaved, time consuming and expensive. According to Langley et al, (2001) the technology of remote sensing offers a practical and economical means to carry out mangrove study especially over a large area. Two remote sensing methods were adopted in this study: Supervised image 
classification and Normalized Difference Vegetation Index (NDVI).

Worldview-2 image acquired in $9^{\text {th }}$ January 2013 was geometrically corrected, rectified to the true ground positions and projected to the Transverse Mercator Nigeria Mid-Belt (WGS-1984) and referenced to the Minna Datum. The georeferenced image was processed with Erdas Imagine 2010 version. False color composite was created to aid image interpretation and processing because it gives a better visual impression of the reality on the ground. False color composite scheme allows vegetation to be detected readily in the image as vegetation appears in different shades of red depending on the types and conditions of the vegetation, since it has a high reflectance in the NIR band. In interpreting the image, proxy that could be used to determine the presence/impact of oil spill in the image was used. Direct method based on texture and spectral signature was also utilized. Elements of image interpretation such as shape, hue, pattern and texture also aided in the interpretation. These elements were used in the selection of the training sites. Supervised classification method and Maximum Likelihood Classification (MLC) Algorithm were carried out on the image.

\subsection{Normalized Difference Vegetation Index (NDVI)}

Ajibola (2009) noted that assessment and modeling of oil spill impact would yield more reliable result if approached from NDVI perspective than from vegetal cover area. NDVI is a mapping technique used to show the behavior of vegetal cover in relation to the environmental condition. This spatial behavior/variability is useful to assess vegetal cover. It is often directly related to other ground parameters such as percent of ground cover, photosynthetic activity of the plant, surface water, leaf area index and the amount of biomass. Healthy vegetation has a low reflectance within the visible light range (from 0.4 to $0.7 \mu \mathrm{m}$ ), since it is strongly absorbed by the leaf pigments (chlorophyll) for photosynthesis, and high reflectance in the near-infrared light range (from 0.7 to $1.1 \mu \mathrm{m}$ ) a dying or scenesing leaf has less photosynthetic activity and the cell structure of the leaf collapses resulting in an increase of reflected visible light and a decrease of reflected near-infrared light.

Generally, healthy vegetation will absorb most of the visible light that falls on it, and reflects a large portion of the near-infrared light. Unhealthy or sparse vegetation reflects more visible light and less near-infrared light. Bare soils on the other hand reflect moderately in both the red and infrared portion of the electromagnetic spectrum (Holme et al 1987). This spectral behavior is useful to assess plant vigor and to separate canopy from bare soil. The spectral behavior of the leaf changes during senescence and in plants subjected to stress (e.g. disease, pest, and Nitrogen shortage) by reflecting more Red lights and absorbing more NIR. Opposite behavior is shown in healthy plants with high values of reflectance in the NIR region and low values in Red portion (Pinter et al., 2003). The normalized difference vegetation index (NDVI) is often used to monitor vegetation dynamics (Julien, Sobrino, \& Verhoef, 2006; and Zhou et al., 2001). It has been shown to be highly correlated with plant health, vegetation density, and cover (Ormsby, Choudhury, \& Owe, 1987). The NDVI algorithm subtracts the red reflectance values from the near-infrared and divides it by the sum of nearinfrared and red bands. NDVI is calculated by the formula:

$\mathrm{NDVI}=(\mathrm{NIR}-\mathrm{RED}) /(\mathrm{NIR}+\mathrm{RED})$

Applying the concept of normalization, the comparison of absorbed incident light to reflected can be placed in a simple ratio that exists on a scale varying between -1.0 and 1.0 making evaluation of environmental responses comparable (Crippen, 1990). The higher the index, the more vigorous the vegetation of the observed area. Very low values ( 0.1 and below) correspond to barren areas of rock, sand and snow or areas that have been burnt. Moderate values $(0.2$ to 0.3$)$ usually indicate shrub and grassland, while temperate and tropical rainforests are represented by very high NDVI values (0.6 to 0.8) (Crippen, 1990). Vegetation index has a direct relation with the quantity, quality and development of vegetation and it correlates well with the yield of a given field. Vegetated areas will generally yield high values because of their relatively high near-infrared reflectance and low visible reflectance.

\section{Findings and Discussion}

The result of the supervised classified worldview 2 image of 2013 is shown in figure 1 while Figure 2 is the Normalized Difference Vegetation Index of the same image. Figure 1 reveals stressed mangrove vegetation which covers about 37.6 $\mathrm{km}^{2}$ and also oil on water covering $9.2 \mathrm{~km}^{2}$ in area. Figure 2, the NDVI of 2013 Worldview-2 image gave index that ranges between -0.39 and 0.55 . More area show low photosynthetic activity especially the disturbed areas. Areas with stressed vegetation have an index of -0.39 indicating that the mangrove vegetations are dead. Consequently, this indicates reduction in mangrove cover. Area with oil on water did not show on the NDVI because oil only reflects in the blue band. Note that the NDVI was generated using red and Near Infrared. 


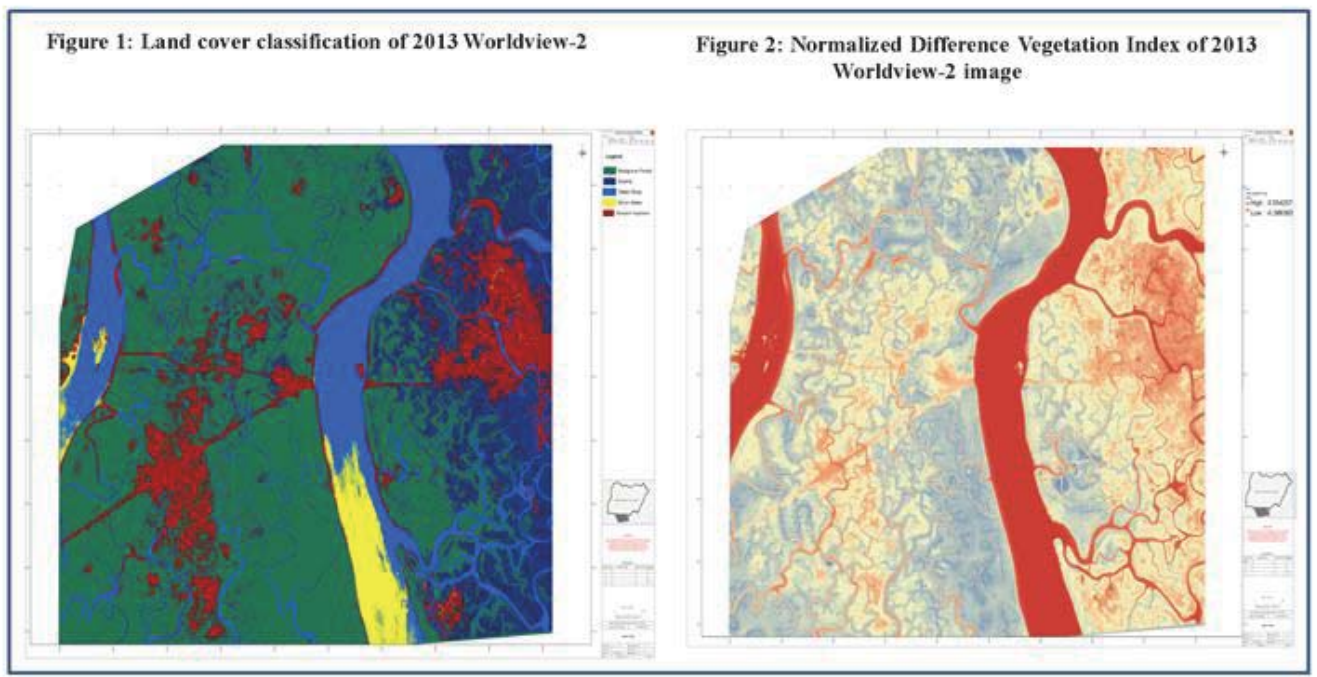

When zoomed in on the area with stressed vegetation in the worldview-2 raw image it reveals structures that the author interpreted as illegal refineries. Elements of photo- interpretation and other collateral information such as aerial photographs were used to verify this. Figure 3 shows that the illegal refineries are co-located with the impacted areas. It is observed that these illegal refineries clustered around a major oil pipeline which has been reported to have suffered illegal bunkering several times in 2012 and 2013. This may tend to suggest that illegal refineries activities could have been responsible for the observed mangrove stressed.

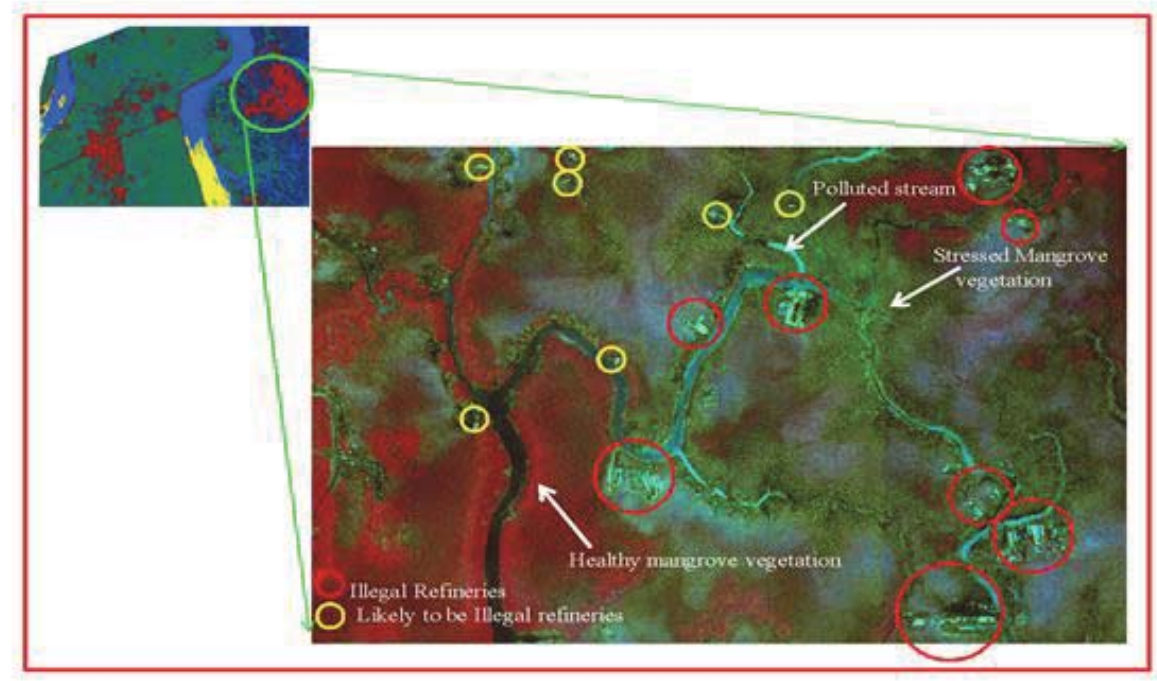

The study demonstrated that it is possible to assess the condition of the mangrove ecosystem using remote sensing data. On the land, mangrove condition is detectable using the reflectance characteristic of the stress vegetation as proxy. The affected area reflects in the optical image (2013 Worldview-2) differently and was also well captured in the NDVI. The NDVI prove to be a useful tool that corroborates the result of the processed image. The study reveals that some areas which were previously covered by swamps and mangroves are experiencing disturbance from crude oil spill. The amount of oil theft going on in the Niger Delta region according to report would suggest that there exist many of these illegal refineries within the mangroves. This being the case more area outside the study area might have been impacted. That would be a major threat to mangrove forest in the Niger Delta. 


\section{Conclusion}

The study demonstrated the potentials of remote sensing method in detecting and mapping the impacts oil spill in the mangrove. It also reveals that the mangrove is experiencing some significant changes due to oil spillages arising majorly from oil bunkering and illegal refinery. The loss of mangrove forests is not only degrading life for plants and animals, but for humans as well since the mangrove products are critical source of income to the people. Oil bunkering and illegal refining activities taking place within the creeks and environs are a challenge and threat to the nation economy and environment. Due to the increasing waves of crude oil theft and illegal refineries in the region and its impacts on the mangroves and on those who depend on the mangrove products for their sustenance this study suggests a regional survey of the mangrove in the Niger Delta using optical remote sensing method.

\section{References}

Africapractice (2012). Nigeria: The Murky World of Oil Theft Issue 137/ October www.africapractice.com

Ajibola-James, O. (2009). Remote Sensing Approach for Assessing and Modeling Mangrove Vegetation Recovery from Crude Oil Spillage Impact in the Niger Delta. Internship Research Report submitted to The Shell Petroleum Development Company of Nigeria Limited

Anderson, I. (2005). Niger River basin: A Vision for Sustainable Development Pp. 1-131 The World Bank,

Attah, T. (2012). Oil Theft and Artisanal (illegal) Refining in Nigeria - Scale, Impacts and the need for a multi-dimensional response. Chatham House - Gulf of Guinea Security Conference, London Vice President HSE \& Corporate Affairs, Shell Sub-Saharan Africa December 6 ,

Baird, J. (2010). "Oil's Shame in Africa". Newsweek: 27.

Basso, B., Cammarano, D., \& De Vita, P. (2004). Remotely Sensed Vegetation Indices: Theory and Applications for Crop Management. Rivistaltaliana di Agrometeorologia 36-53 (1)

Blasco, F., Saenger, P., \& Janodet. E. (1996). Mangroves as indicators of coastal change. Catena, 27: 167-178

Boullion, S., Borges, A.V., Castañeda-Moya, E., Diele, K., Dittmar, T., Duke, N.C., Kristensen, E., Lee, S.Y., Marchand, C., Middelburg, J.J., Rivera-Monroy, V.H., Smith, T.J., III, \& Twilley, R.R. (2011). Mangrove production and carbon sinks: A revision of global budget estimates. Glob. Biochem. Cycles 2008, 22, GB 2013, 1-12. Remote Sens., 3920

Boyd, C. E., \& Tucker, C. S. (1998). Pond aquaculture water quality management. Springer Publishing. New York.

Boyer, J.S. (1982). Plant productivity and the environment. Science. 218:443-448.

Cannicci, S., Burrows, D., Fratini, S., Smith, T.J., Offenberg, J., \& Dahdouh-Guebas, F. (2008). Faunal impact on vegetation structure and ecosystem function in mangrove forests: A review. Aquat. Bot., 89, 186-200.

Carter, G.A., \& Knapp, A.K. (200). Leaf optical properties in higher plants: linking spectral characteristics to stress and chlorophyll concentration. American J. of Botany. 88:677-684.

Chan, E.I. (1977). Oil pollution and tropical littoral communities. Biological Effects of the 1975 Florida Keys Oil Spill. In: Proceedings of the 1977 Oil Spill Conference. J. O. Ludgwigson ed. Pp 539-542. American Petroleum Institute, U.S.

Crippen, R.E. (1990). Calculating the vegetation Index Faster. Remote Sensing of Environment. 34:71-73.

Holme, A. McR., Burnside, D.G., \& Mitchell, A.A. (1987). The development of a system for monitoring trend in range condition in the arid shrublands of Western Australia. Australian Rangeland Journal 9:14-20.

Jacobi, C.M. \& Schaeffer-Novelli, Y. (1990). Oil spill in Mangroves: a conceptual model based on long term field observation. Ecological modeling 52:53-59

Julien, Y., Sobrino, J. A., \& Verhoef, W. (2006). Changes in land surface temperatures and NDVI values over Europe between 1982 and 1999. Remote Sensing of Environment, 103(1), 43-55.

Kathiresan, K., \& Bingham, B. (2001). Biology of mangroves and mangrove ecosystems. Adv. Mar. Biol., 40, 81-251.

Kristensen, E., Bouillon, S., Dittmar, T., \& Marchand, C. (2008). Organic carbon dynamics in mangrove ecosystems: A review. Aquat. Bot., 89, 201-219.

Kuenzer, C., Bluemel, A., Gebhardt, S., Quoc, T. V., \& Dech. S. (2011). Remote Sensing of Mangrove Ecosystems: A Review. Remote Sens., 3, 878-928; doi: 10.3390/rs3050878

Langley, S.K, Cheshire, H.M, \& Humes, K.S (2001). A comparison of single date and multitemporal satellite image classifications in a semi-arid grassland. J Arid Environ 49:401-11.Lewis, R. R. (1979). Oil and Mangrove Forests: the Aftermath of the Howard Star Oil Spill. Florida Scientist 42 (suppli.): 26. (Abst.)

Lewis, R. R. (1980). Oil and mangrove forests: observed impact 12 months after the Howard Star oil spill. Florida Scientist 43 (suppli.): 23. (Abst.)

Lewis, R.R. (1983). Impact of oil spill on mangrove forests. Pp171-183 in H.J. Teas (ed) Biology and Ecology of mangroves. Tasks for Vegetation Science 8. The Hague.

Manson, F.J., Loneragan, N.R., Skilleter, G.A., \& Phinn, S.R. (2005). An evaluation of the evidence for linkages between mangroves and fisheries: A synthesis of the literature and identification of research directions. In Oceanography and Marine Biology: An Annual Review; Gibson, R.N., Atkinson, R.J.A., Gordon, J.D.M., Eds.; Taylor and Francis: London, UK, Volume 43, pp. 485-515.

Mumby, P.J., Edwards, A.J., Arias-Gonzáles, E., Lindeman, K.C., Blackwell, P.G., Gall, A., Gorczynska, M.ı., Harborne, A.R., Pescod, 
C.L., Renken, H., Wabnitz, C.C., \& Llewellyn, G. (2004). Mangrove enhance the biomass of coral reef fish communities in the Caribbean. Nature, 427, 533-536.

Nagelkerken, I., Blaber, S.J., Bouillon, S., Green, P., Haywood, M., Kirton, L.G., Meynecke, J. O., Pawlik, J., Penrose, H.M., Sasekumar, A., \& Somerfield P.J. (2008). The habit function of mangroves for terrestrial and marine fauna: A review. Aquat. Bot., 89, 155185.

Naylor, R.L., Goldburg, R.J., Primavera, J.H., Kautsky, N., Beveridge, M.C., Clay, J., Folke, C., Lubchenco, J., Mooney, H., \& Troell, M. (2000). Effect of aquaculture on world fish supplies. Nature, 405, 1017-1024.

Ormsby, J. P., Choudhury, B. J., \& Owe, M. (1987). Vegetation spatial variability and its effect on vegetation indices. International Journal of Remote Sensing, 8(9), 1301-1306.

Osuji, L.C., Erondu, E.S., \& Ogali, R.E (2010). Upstream Petroleum Degradation of Mangroves and Intertidal Shores: the Niger Delta experience. ChemBiodivers, 7(1):116-28. doi: 10.1002/cbdv.200900203.

Pinter, Jr., P.J., Ritchie, J.C., Hatfield, J.L., \& Hart, G.F. (2003). The Agricultural Research Service's remote sensing program: An example of interagency collaboration, Photogrammetric Engineering and Remote Sensing, 69(6):615-618.

Proffitt, C.E. (ed) (1996). Managing Oil Spills in Mangrove Ecosystems: Effects, Remediation, Restoration and Modeling. OCS Study MMS 97-0003. New Orleans: US Department of the Interior, Minerals Management Service, Gulf of Mexico, OCS Region. 76pp.

Ruitenbeck, J.H. (1990). Economic Analysis of Tropical Forest Conservation Initiatives: Example from West Africa. World Wide Fund for Nature.

Ramachandran, S., Sundaramoorty, S., Krishnamoorty, S., Devasenapaty, J., \& Thanikachalam, M. (1998). Application of remote sensing and GIS to coastal wetland of Tamil Nadu. Current Science, 75(3), 236-239.

Shigenaka, G. (2002). Oil spill in Mangrove: Oil toxicity. Office of Response and Restoration, NOAA Ocean Service, National Oceanic and Atmospheric Administration, Seattle, Washington.

Snedaker, S. C., Jimenze, J.A \& Brown, M.S. (1981). Anomalous aerial roots in Avicennia germinans (L) in Florida and Costa Rica. Bull. Mar. Sci. 31:467-470

Xiao, X.M., Zhang, Q., \& Braswell, B, et al. (2004). Modeling gross primary production of temperate deciduous broadleaf forest using satellite images and climate data. Remote Sens Environ 91:256-70.

Zhao, D., Reddy, K. R., Kakani, V.G., Read, J.J., \& Carter, G.A. (2003). Corn (Zea mays L.)

growth, leaf pigment concentrations, photosynthesis and leaf hyperspectral reflectance properties as affected by nitrogen supply. Plant and Soil. 257:205-217.

Zhou, L., Tucker, C. J., Kaufmann, R. K., Slayback, D., Shabanov, N. V., \& Myneni, R. B. (2001). Variations in northern vegetation activity inferred from satellite data of vegetation index during 1981-1999. Journal of Geophysical Research, 106(20), 69-83. 